\title{
Estimating cropland carbon mitigation potentials in China affected by three improved cropland practices
}

LUN Fei ${ }^{1,2,3}$ iD http://orcid.org/oooo-0003-0978-9936; e-mail: rucallen_2008@hotmail.com

Josep G. CANADELL4 iD http://orcid.org/oooo-ooo2-8788-3218; e-mail: pep.canadell@csiro.au

HE Lu5 ${ }^{\text {iD }}$ http://orcid.org/oooo-0oo2-3733-3015; e-mail:1518936543@qq.com

YANG Bo6 ${ }^{6}$ http://orcid.org/oooo-0oo3-0582-2874; e-mail:snihc-0626@163.com

LIU Mou-cheng7 iD http://orcid.org/oooo-00o2-4444-3482; e-mail: liumc@igsnrr.ac.cn

YUAN Zheng7 iD http://orcid.org/oooo-0oo2-0271-4225; e-mail: yuanz.11b@igsnrr.ac.cn

TIAN Mi7 (D http://orcid.org/oooo-00o2-7953-558X; e-mail: yuanz.11b@igsnrr.ac.cn

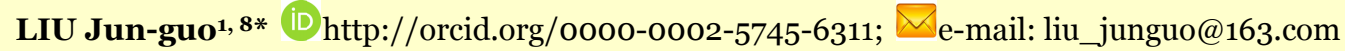

LI Wen-hua7 iD http://orcid.org/oooo-0oo1-9614-4890; e-mail: liwh@igsnrr.ac.cn

\author{
${ }^{*}$ Corresponding author \\ 1 School of Nature Conservation, Beijing Forestry University, Qinghua East Road 35, Beijing 100083, China \\ 2 College of Resources and Environment Sciences, China Agricultural University, Beijing 100193, China \\ 3 Center of Land Policy and Law, Beijing 10o193, China \\ 4 Global Carbon Project, CSIRO Marine and Atmospheric Research, GPO Box 3023, Canberra, ACT 2601, Australia \\ 5 World Natural Heritage Conservation and Research Center, Ministry of Housing and Urban-Rural, No. 9 Sanlihe, Beijing \\ 10085, China \\ 6 Beijing Academy of Social Sciences, No.33 Beisihuanzhonglu, Beijing 10o101, China \\ 7 Institute of Geographic Sciences and Natural Resources Research, Chinese Academy of Sciences, 11A Datun Road, Beijing \\ 100101, China. \\ 8 School of Environmental Science and Engineering, South University of Science and Technology of China, Shenzhen 518055, \\ China
}

Citation: Lun F, Canadell JG, He L, et al. (2016) Estimating cropland carbon mitigation potentials in China affected by three improved cropland practices. Journal of Mountain Science 13(10). DOI: 10.1007/s11629-015-3813-2

(C) Science Press and Institute of Mountain Hazards and Environment, CAS and Springer-Verlag Berlin Heidelberg 2016

\begin{abstract}
Agriculture is a large source of carbon emissions. The cropland practices of fertilizer substitution, crop straw and conservation tillage are beneficial and help to rebuild local soil carbon stocks and reduce soil carbon emissions, in addition to reducing the consumption of fertilizers and fossil fuels. These improved cropland practices can directly and indirectly mitigate
\end{abstract}

Received: 20 December 2015

Revised: 24 March 2016

Accepted: 7 April 2016 carbon emissions, benefiting the sustainability of croplands. For these three improved practices, we estimated carbon mitigation potentials in rice, wheat and maize croplands in China. The combined contribution of these practices to carbon mitigation was $38.8 \mathrm{Tg} \mathrm{C} \mathrm{yr}^{-1}$, with fertilizer substitution, crop straw return, and conservation

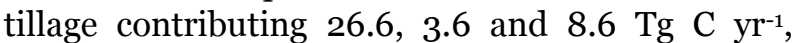
respectively. Rice, wheat and maize croplands had potentials to mitigate $13.4,11.9$ and $15.5 \mathrm{Tg} \mathrm{C} \mathrm{yr}^{-1}$, respectively, with the combined direct and indirect 
potential of 33.8 and $5.0 \mathrm{Tg} \mathrm{C} \mathrm{yr}^{-1}$. Because of differences in local climate and specific diets, the regional cropland carbon mitigation potentials differed greatly among provinces in China. In China, 18 provinces had a "target surplus" for which the carbon mitigation from these three practices was larger than the mitigation target set for 2020. At the national level, a net "target surplus" of $4.84 \mathrm{Tg} \mathrm{C} \mathrm{yr}^{-1}$ would be attained for Chinese croplands with full implementation of the three improved practices. Regional cooperation must be developed to achieve carbon mitigation targets using such measures as carbon trading, establishing regional associations, and strengthening research programs to improve practices.

Keywords: Cropland; Carbon mitigation potential; Cropland practices; Regional cooperation; China

\section{Introduction}

Agriculture occupies 37\% of global land, which is responsible for an estimated $1.4 \%$ to $10 \%-12 \%$ of the approximately $1.7 \mathrm{Pg} \mathrm{CO}_{2}$-eq $\mathrm{yr}^{-1}$ of global greenhouse gas (GHG) emissions (Smith et al. 2007). GHG emissions come from a variety of practices in the agricultural sector, including soil drainage, soil tillage, biomass burning, flooding, and excess use of fertilizers (West and Marland 2002a; Smith et al. 2007; Li et al. 2011). Some of these practices can directly influence the soil properties and therefore are harmful to long-term cropping sustainability, particularly those that affect soil carbon storage. Current unsustainable practices result in carbon loss of $30-60 \mathrm{Mg} \mathrm{C}^{-1}$ from agricultural soils, which accumulated to $78 \pm 12$ Pg C (Lal 2007). Thus, to avoid further soil carbon loss, it is essential to improve cropland practices.

Many improved cropland practices are implemented, including reduced tillage or notillage, improved crop rotations, applications of organic amendments, return of crop residues, improved irrigation, organic farming, among other practices (Smith et al. 2007, 2008; Paustian et al. 2000; Lu et al. 2009; West et al. 2002a, 2002b, 2002c; Freibauer et al. 2004; Müller et al. 2015; Frank et al. 2015; Sanchez et al. 2016). With these improved cropland practices, the maintenance of cropland soil carbon stocks improves, and therefore, the practices can directly or indirectly reduce cropland carbon emissions (Paustian et al. 2000; Lu et al. 2009). When implemented, these improved cropland practices could mitigate approximately 5500-6000 $\mathrm{Mt} \mathrm{CO}_{2}$-eq $\mathrm{yr}^{-1}$ globally (Smith et al. 2008).

As the world's largest carbon emitter (Peters et al. 2012), China has committed to a reduction of 40\%-45\% in its carbon emissions intensity (carbon emissions per GDP) by 2020, compared with that in 2005 (Fan and Xia 2012). Therefore, China faces a serious burden in mitigating carbon emissions in the near future, and the demand is high for further practices that mitigate carbon emissions for those sectors with high carbon intensities, like the agriculture sector. However, with the increase of population, food demand is also rapidly growing. Although cropland in China is limited, with 120 million ha, agriculture intensification has led to rapid increases in annual crop yields, supported by tremendous consumption of fertilizers and fossil fuels (Huang and Sun 2006; Qiu et al. 2009; Pan et al. 2009; Fan et al. 2012). With this intensification, environmental problems have occurred, such as declines in cropland soil carbon stocks, excessive $\mathrm{N}_{2} \mathrm{O}$ emissions, and increases in cropland $\mathrm{CO}_{2}$ emissions. Additionally, other unsuitable practices also contribute to large increases in carbon emissions from the agriculture sector; for example, the burning of crop residues in open fields led to 2707.34 $\mathrm{Tg}$ of $\mathrm{CO}_{2}$ emissions in China from 1996 to 2013 (Sun et al. 2016). Consequently, carbon emissions from cropland increased from $43.07 \mathrm{Tg}$ $\mathrm{C}$ in 1993 to $78.43 \mathrm{Tg} \mathrm{C}$ in 2008, with an increasing rate of $4.08 \%$ ( $\mathrm{Li}$ et al. 2011). Thus, the identification of practices that mitigate carbon emissions from cropland in China is essential.

Many studies have examined how improved cropland practices reduce carbon emissions in China (Xu et al. 2011; Yan et al. 2015; Chuai et al. 2015; Ponsioen and Blonk 2012; Wang et al. 2014, 2015; Nayak et al. 2015), including conservation tillage (Cheng et al. 2014; Xu et al. 2012; Han et al. 2010; Wu et al. 2007), crop straw management ( $\mathrm{Lu}$ et al. 2009 2010; Li et al. 2011; Cheng et al. 2013; Huang et al. 2013), manure inputs (Pan et al. 2009; Shen et al. 2007; Zhu et al. 2012), organic farming (Ouyang et al. 2011), and crop rotation (Huang et al. 2012). From these studies, the potential of Chinese 
agriculture for carbon sequestration was estimated to range from 0.4 to $0.9 \mathrm{Pg} \mathrm{C} \mathrm{yr}^{-1}$ (Pan et al. 2003; Han et al. 2005; Yan et al. 2007; Lu et al. 2009). However, some of these practices are neither environmentally-friendly nor sustainable (e.g., the $\mathrm{N}_{2} \mathrm{O}$ emissions associated with large-scale fertilizer use). To bridge the gaps in information for China, our study aimed to (1) estimate the cropland carbon mitigation potentials of three environmentally-friendly, improved cropland practices of fertilizer substitution, crop straw return and conservation tillage; (2) calculate the direct and indirect carbon mitigation potentials of rice, wheat and maize croplands at different levels; (3) compare cropland carbon mitigation potentials with their carbon reduction targets; and (4) discuss regional cooperation can better achieve the regional and national carbon reduction targets.

\section{Data and Methodology}

We estimate the technical carbon mitigation potentials in China for three improved cropland practices: (1) Fertilizer Substitution with Manure: to replace $\mathrm{N}, \mathrm{P}$ and $\mathrm{K}$ fertilizers with manure to fully use the livestock excreta that is currently disposed as waste; (2) Crop Straw Return: to return more of the crop residues to croplands, including those that are currently and directly burnt in the open field; and (3) Conservation Tillage: to replace conventional tillage. For these three improved cropland practices, we estimated the direct carbon mitigation potentials (including the increase in carbon sequestration and the reduction in carbon emissions) and the indirect carbon mitigation potentials (including less carbon emissions from less external consumption of fertilizers and fossil fuels). The reference year for all data was 2008, which included areas, yields and incomes of rice, wheat and maize croplands, and the consumption of $\mathrm{N}, \mathrm{P}$ and $\mathrm{K}$ fertilizers. The information is obtained from China Rural Statistical Yearbook, China Statistical Yearbook, and China Statistical Yearbook on Environment.

Considering the local climates, cropping varieties and cultivation practices, Chinese cropland were divided into four primary regions (See Figure 1) as follows (Lu et al. 2009):

Region I: Northeast China, including

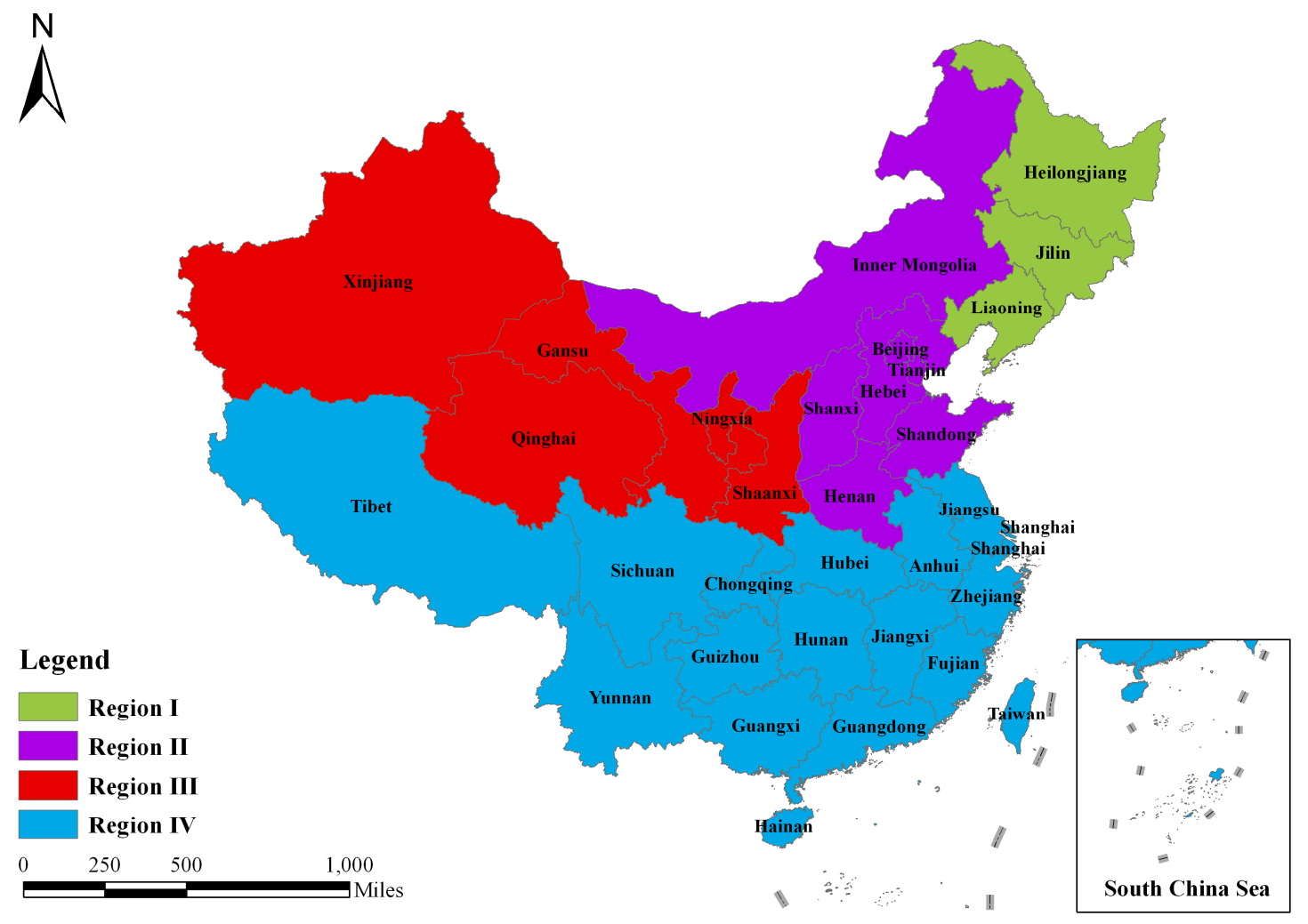

Figure 1 The distribution of the four cropland regions in China. 
Heilongjiang, Jilin, and Liaoning.

Region II: North China, including Inner Mongolia, Shanxi, Hebei, Henan, Beijing, Tianjin, and Shandong.

Region III: Northwest China, including Shaanxi, Gansu, Ningxia, Qinghai, and Xinjiang.

Region IV: South China, including Jiangsu, Anhui, Shanghai, Zhejiang, Fujian, Jiangxi, Hubei, Hunan, Guangdong, Guangxi, Chongqing, Sichuan, Guizhou, Yunnan, Hainan and Tibet, with Hong Kong, Macao and Taiwan not being included in this study because of the lack of data.

\subsection{Fertilizer substitution by manure}

Approximately $28.3 \%$ of livestock excreta in China is disposed as waste (Qiu et al. 2012). For the practice of fertilizer substitution by manure, we supposed that the manure replaced chemical fertilizers, leading to less consumption of fertilizers. In the year of 2008, 3000 million ton (Mt) of livestock excreta were produced in China, with 850 Mt being disposed as waste (Sun and Song 2008). Sun et al. (2005) estimated that $1 \mathrm{t}$ of wasted livestock excreta can replace $5.65 \mathrm{t}, 1.13 \mathrm{t}$ and $4.26 \mathrm{t}$ of $\mathrm{N}, \mathrm{P}$ and $\mathrm{K}$ fertilizers, respectively. Therefore, the total $850 \mathrm{Mt}$ of wasted excreta could substitute for $4.8 \mathrm{Mt}, 0.96 \mathrm{Mt}$ and $3.62 \mathrm{Mt}$ of $\mathrm{N}, \mathrm{P}$ and $\mathrm{K}$ fertilizers, respectively. In 2008, the total consumption of the three croplands was approximately 12.4 Mt of N, 4.2 Mt of P and 2.9 Mt of $\mathrm{K}$ fertilizers, respectively. Thus, if the total wasted excreta was fully used as manure, $39 \%$ of N, $23 \%$ of $\mathrm{P}$ and $100 \%$ of $\mathrm{K}$ fertilizers would be saved, equivalent to the substitution rates.

As noted by Triberti et al. (2008), application of livestock manure is beneficial for soil organic carbon sequestration and storage, with a carbon

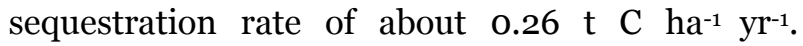
Therefore, the direct carbon mitigation by fertilizer substitution originates from the increase in soil carbon sequestration. Thus, the direct carbon mitigation potential by "fertilizer substitution" was estimated with the following equation:

$$
M C_{\text {direct }}=a_{m c} \sum A_{i}
$$

where $M C_{\text {direct }}$ denotes the direct carbon mitigation by fertilizer substitution, $a_{m c}$ is the increase in soil carbon sequestration from manure inputs, approximately $0.26 \mathrm{t} \mathrm{C} \mathrm{ha}^{-1} \mathrm{yr}^{-1}$ (Triberti et al.
2008), and $A_{i}$ is the area of rice, wheat or maize cropland.

In addition to the increase in soil carbon sequestration, fertilizer application also leads to carbon emissions during the processes of production and consumption (West and Marland 2002a). Thus, the lower fertilizer consumption would reduce this portion of carbon emissions, which is an indirect form of carbon mitigation that results from fertilizer substitution. Additionally, because of the limited data in China, our calculations relied on two conservative assumptions: (1) the carbon emissions are identical for the transport and delivery of manure and fertilizers, and (2) the emissions of $\mathrm{CH}_{4}$ and $\mathrm{N}_{2} \mathrm{O}$ are identical from the disposal of waste livestock excreta and the application as manure. Thus, the indirect carbon mitigation from fertilizer substitution was estimated as follows:

$$
M C_{\text {indirect }}=\sum b_{m c i} C F_{m c i}
$$

where $M C_{\text {indirect }}$ is the indirect carbon mitigation from fertilizer substitution, $b_{m c i}$ are carbon emissions from consuming $\mathrm{N}, \mathrm{P}$ and $\mathrm{K}$ fertilizers, with the emission rates of $857.5 \mathrm{KgC} \mathrm{Mg}^{-1}$ for $\mathrm{N}$, 165.1 $\mathrm{KgC} \mathrm{Mg}^{-1}$ for $\mathrm{P}$, and $120.3 \mathrm{KgC} \mathrm{Mg}^{-1}$ for $\mathrm{K}$ fertilizers (West and Marland 2002a); $C F_{m c i}$ are the substitution rates for $\mathrm{N}, \mathrm{P}$ and $\mathrm{K}$ fertilizers, approximately $39 \%, 23 \%$ and $100 \%$, respectively.

\subsection{Crop straw return}

Because crop straw is a primary precursor of soil organic carbon, the return of crop straw to soils increases soil carbon storage (Smith et al. 2008). In China, crop straw is used for biomass fuel (47\%), livestock forage (20\%), industrial raw materials (3\%), and returned to the soil (15\%); however, the remaining $15 \%$ of crop straw is burned in open fields as waste, which increases the environmental problem of air pollution (Wang et al. 2008). Therefore, with the return of the crop straw from open-field burning, soil organic carbon inputs increase and the local environment also benefits. With all the open-field burned crop straw being returned to the soil; we assumed that the proportion of crop straw return increased from 15\% to $30 \%$. As noted by Lu et al. (2009), soil organic carbon storage is linearly correlated with the amount of crop straw returned; the relationships 
are summarized by region in China as follow:

Region I (Northeast China): $S C S=40.254 S+$ 340.33 181.9

Region II (North China): $S C S=40.607 S+$

Region III (Northwest China): $S C S=17.116 S+$ 30.553

Region IV (South China): $S C S=43.548 S+$ 375.1

where $S$ is the crop straw returned ( $\mathrm{t} \mathrm{ha}^{-1} \mathrm{yr}^{-1}$ ), and $S C S$ is the soil carbon sequestration $\left(\mathrm{kg} \mathrm{C} \mathrm{ha}^{-1}\right.$ $\left.\mathrm{yr}^{-1}\right)$.

The annual yield of crop straw $\left(S_{i}\right)$ was estimated by crop yield $\left(Y_{i}\right)$ and the straw-grain ratio $\left(S G R_{i}\right)$, with $S G R s$ of $0.623,1.366$ and 2.000 for rice, wheat and maize, respectively ( $\mathrm{Lu}$ et al. 2009).

$$
S_{i}=Y_{i} \times S G R_{i}
$$

Thus, crop straw return leads to an increase in soil carbon storage, which is the direct carbon mitigation potential. Moreover, no indirect carbon mitigation results from crop straw return. Consequently, the direct carbon mitigation potential by crop straw return was calculated as follows:

$$
S R C_{\text {direct }}=S C S_{30 \%}-S C S_{15 \%}
$$

where $S R C_{\text {direct }}$ denotes direct carbon mitigation from crop straw return and $S C S_{30 \%}$ and $S C S_{15 \%}$ are levels to soil carbon sequestration with crop straw return ratios of $30 \%$ and $15 \%$, respectively.

\subsection{Conservation tillage}

The dominant tillage practice in China, conventional tillage with moldboard plowing, changes the structure of soil organic matter and also increases microbial activity. Thus, compared with conservation tillage (primarily no-tillage), conventional practice increases the decomposition of organic matter, leading to an increase in carbon emissions (Wright and Hons 2005; Fabrizzi et al. 2009; $\mathrm{Xu}$ et al. 2011). Additionally, tractors consume fossil fuel in plowing during conventional tillage, leading to carbon emissions of $0.3868 \mathrm{~kg} \mathrm{C}$ ha $^{-1}$ (Lal 2004; Wu et al. 2007). Therefore, with conservation tillage (particularly no-tillage), the carbon mitigation potential is significant (West and Post 2002c; Lal 2004; Smith et al. 2008). For conservation tillage, we assumed that $50 \%$ of the cropland in conventional tillage was converted to conservation tillage. For this practice, the direct carbon mitigation refers to the carbon emissions from conventional tillage, whereas the indirect mitigations from less fossil fuel consumption. Thus, the potentials for direct and indirect carbon mitigation under conservation tillage were determined as follow:

$$
\begin{aligned}
& N T C_{\text {direct }}=N T S C_{i} A_{i} \\
& N T C_{\text {indirect }}=0.3868 \times N T A_{i}
\end{aligned}
$$

where $N T C_{\text {direct }}$ and $N T C_{\text {indirect }}$ are the direct and indirect carbon mitigation by conservation tillage, $N T S C_{i}$ is soil carbon emissions by conventional tillage, with 255, 157, 390 and $198 \mathrm{~kg} \mathrm{C} \mathrm{ha}^{-1} \mathrm{yr}^{-1}$ for Regions I, II, III, and IV, respectively (Lu et al. 2009), and $N T A_{i}$ is the area in conservation tillage (50\% of the cropland area).

\section{Results}

The potentials for carbon mitigation with the application of the three improved practices in the three types of cropland are shown in Table 1 for all provinces in China (except for Hong Kong, Macao and Taiwan).

\subsection{Carbon mitigation potential by fertilizer substitution}

Substituting chemical fertilizer with manure in cropland contributed a carbon mitigation potential of $26.6 \mathrm{Tg} \mathrm{C} \mathrm{yr}-1$ in China, approximately $320.5 \mathrm{~kg}$ $\mathrm{C} \mathrm{ha-1} \mathrm{yr}^{-1}$, which included the direct mitigation of $21.6 \mathrm{Tg} \mathrm{C} \mathrm{yr} \mathrm{r}^{-1}$ and indirect the potential of $5.0 \mathrm{Tg} \mathrm{C}$ $\mathrm{yr}^{-1}$. The difference in carbon mitigation potentials of rice, wheat and maize were not significant after fertilizer substitution, which were 9.6, 7.6, and 9.3 $\mathrm{Tg} \mathrm{C} \mathrm{yr}^{-1}$, respectively. Geographically, the largest overall contributor was Henan at $2.8 \mathrm{Tg} \mathrm{C} \mathrm{yr}^{-1}$, which had the largest direct and indirect carbon mitigation potentials of 2.3 and $0.6 \mathrm{Tg} \mathrm{C} \mathrm{yr}{ }^{-1}$, respectively. Following Henan, fertilizer substitution in Shandong also contributed a large

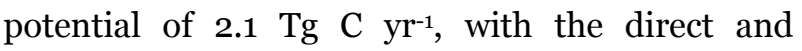

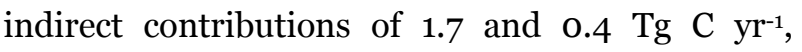
respectively. The carbon mitigation from this practice was relatively small in Tibet $\left(0.01 \mathrm{Tg} \mathrm{C} \mathrm{yr}^{-1}\right)$ and Qinghai (0.03 $\mathrm{Tg} \mathrm{C} \mathrm{yr}^{-1}$ ), because both 
Table 1 Cropland carbon mitigation potential from improved practices in China (Unit: $\mathrm{Tg} \mathrm{C} \mathrm{yr}^{-1}$ )

\begin{tabular}{|c|c|c|c|c|c|c|c|c|c|c|c|}
\hline \multirow{2}{*}{ Region } & \multirow{2}{*}{ Province } & \multicolumn{3}{|c|}{ Fertilizer substitution } & \multirow{2}{*}{\begin{tabular}{|l|} 
Straw return \\
Direct
\end{tabular}} & \multicolumn{3}{|c|}{ Conservation tillage } & \multicolumn{3}{|c|}{ Total } \\
\hline & & Total & Direct & Indirect & & Total & Direct & Indirect & Total & Direct & Indirect \\
\hline \multirow{3}{*}{ Region I } & Liaoning & 0.83 & 0.66 & 0.16 & 0.16 & 0.33 & 0.33 & $4.9 \mathrm{E}-04$ & 1.32 & 1.15 & 0.17 \\
\hline & Jilin & 1.11 & 0.93 & 0.17 & 0.27 & 0.46 & 0.46 & $6.9 \mathrm{E}-04$ & 1.84 & 1.66 & 0.17 \\
\hline & Heilongjiang & 1.79 & 1.64 & 0.15 & 0.28 & 0.80 & 0.80 & $1.2 \mathrm{E}-\mathrm{O} 3$ & 2.88 & 2.73 & 0.15 \\
\hline \multirow{7}{*}{ Region II } & Beijing & 0.07 & 0.05 & 0.02 & 0.01 & 0.02 & 0.02 & 4.1E-O5 & 0.10 & 0.08 & 0.02 \\
\hline & Tianjin & 0.10 & 0.07 & 0.03 & 0.02 & 0.02 & 0.02 & $5 \cdot 5 \mathrm{E}-\mathrm{O} 5$ & 0.14 & 0.11 & 0.03 \\
\hline & Hebei & 1.73 & 1.39 & 0.35 & 0.28 & 0.42 & 0.42 & 1.0E-O3 & 2.43 & 2.09 & 0.35 \\
\hline & Shanxi & 0.62 & 0.54 & 0.08 & 0.10 & 0.16 & 0.16 & 4.0E-O4 & 0.89 & 0.81 & 0.08 \\
\hline & Inner Mongolia & 0.87 & 0.75 & 0.11 & 0.19 & 0.23 & 0.23 & $5.6 \mathrm{E}-\mathrm{O} 4$ & 1.28 & 1.17 & 0.11 \\
\hline & Shandong & 2.09 & 1.70 & 0.39 & 0.40 & 0.51 & 0.51 & $1.3 \mathrm{E}-\mathrm{O} 3$ & 3.01 & 2.61 & 0.40 \\
\hline & Henan & 2.83 & 2.26 & 0.57 & 0.47 & 0.68 & 0.68 & $1.7 \mathrm{E}-03$ & 3.98 & 3.41 & 0.57 \\
\hline \multirow{5}{*}{ Region III } & Shaanxi & 0.80 & 0.63 & 0.17 & 0.04 & 0.47 & 0.47 & $4.7 \mathrm{E}-\mathrm{O} 4$ & 1.31 & 1.14 & 0.17 \\
\hline & Gansu & 0.43 & 0.38 & 0.05 & 0.02 & 0.29 & 0.29 & $2.8 \mathrm{E}-\mathrm{O} 4$ & 0.74 & 0.69 & 0.05 \\
\hline & Qinghai & 0.03 & 0.03 & 0.00 & 0.00 & 0.02 & 0.02 & 2.1E-O5 & 0.05 & 0.05 & 0.00 \\
\hline & Ningxia & 0.21 & 0.13 & 0.08 & 0.01 & 0.10 & 0.10 & $9 \cdot 5 \mathrm{E}-\mathrm{O} 5$ & 0.31 & 0.24 & 0.08 \\
\hline & Xinjiang & 0.49 & 0.40 & 0.09 & 0.04 & 0.30 & 0.30 & 3.oE-O4 & 0.83 & 0.73 & 0.09 \\
\hline \multirow{16}{*}{ Region IV } & Shanghai & 0.06 & 0.04 & 0.02 & 0.01 & 0.02 & 0.02 & $3.0 \mathrm{E}-\mathrm{O} 5$ & 0.08 & 0.06 & 0.02 \\
\hline & Jiangsu & 1.69 & 1.22 & 0.46 & 0.19 & 0.47 & 0.47 & $9.1 \mathrm{E}-\mathrm{O} 4$ & 2.34 & 1.88 & 0.46 \\
\hline & Zhejiang & 0.36 & 0.26 & 0.10 & 0.03 & 0.10 & 0.10 & 2.oE-O4 & 0.50 & 0.40 & 0.10 \\
\hline & Anhui & 1.64 & 1.37 & 0.27 & 0.20 & 0.52 & 0.52 & 1.oE-O3 & 2.37 & 2.09 & 0.28 \\
\hline & Fujian & 0.32 & 0.23 & 0.09 & 0.02 & 0.09 & 0.09 & $1.7 \mathrm{E}-04$ & 0.44 & 0.35 & 0.09 \\
\hline & Jiangxi & 0.98 & 0.85 & 0.13 & 0.08 & 0.33 & 0.32 & $6.3 \mathrm{E}-\mathrm{O} 4$ & 1.38 & 1.25 & 0.13 \\
\hline & Hubei & 1.20 & 0.90 & 0.30 & 0.12 & 0.34 & 0.34 & $6.7 \mathrm{E}-04$ & 1.66 & 1.36 & 0.30 \\
\hline & Hunan & 1.35 & 1.09 & 0.26 & 0.13 & 0.42 & 0.41 & 8.1E-04 & 1.89 & 1.63 & 0.26 \\
\hline & Guangdong & 0.76 & 0.54 & 0.21 & 0.05 & 0.21 & 0.21 & 4.oE-O4 & 1.01 & 0.80 & 0.21 \\
\hline & Guangxi & 0.82 & 0.68 & 0.14 & 0.07 & 0.26 & 0.26 & $5.1 \mathrm{E}-\mathrm{O} 4$ & 1.16 & 1.01 & 0.15 \\
\hline & Hainan & 0.11 & 0.09 & 0.03 & 0.01 & 0.03 & 0.03 & $6.3 \mathrm{E}-\mathrm{O} 5$ & 0.15 & 0.12 & 0.03 \\
\hline & Chongqing & 0.43 & 0.34 & 0.08 & 0.06 & 0.13 & 0.13 & $2.5 \mathrm{E}-\mathrm{O} 4$ & 0.62 & 0.53 & 0.09 \\
\hline & Sichuan & 1.46 & 1.21 & 0.25 & 0.18 & 0.46 & 0.46 & 9.0E-O4 & 2.10 & 1.85 & 0.25 \\
\hline & Guizhou & 0.51 & 0.44 & 0.07 & 0.07 & 0.17 & 0.17 & $3 \cdot 3 \mathrm{E}-\mathrm{O} 4$ & 0.75 & 0.68 & 0.07 \\
\hline & Yunnan & 0.89 & 0.72 & 0.17 & 0.10 & 0.27 & 0.27 & $5.4 \mathrm{E}-\mathrm{O} 4$ & 1.27 & 1.10 & 0.17 \\
\hline & Tibet & 0.01 & 0.01 & 0.00 & 0.00 & 0.00 & 0.00 & $8.2 \mathrm{E}-\mathrm{o} 6$ & 0.02 & 0.02 & 0.00 \\
\hline Total & & 26.59 & 21.57 & 5.02 & 3.62 & 8.63 & 8.61 & 0.02 & 38.83 & 33.80 & 5.04 \\
\hline
\end{tabular}

cropland and fertilizer consumption were limited there.

\subsection{Carbon mitigation potential by crop straw return}

In $2008,6.06 \times 10^{8} \mathrm{t}$ of crop straw were produced in China, including $1.20 \times 10^{8}, 1.54 \times 10^{8}$ and $3.32 \times 10^{8} \mathrm{t}$ from rice, wheat and maize. When crop straw return increased from $15 \%$ to $30 \%$, soil carbon sequestration increased from $3.9 \mathrm{Tg} \mathrm{C} \mathrm{yr}^{-1}$ to

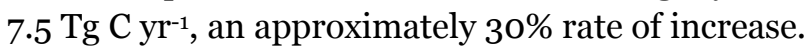
Thus, the direct carbon mitigation potential was $3.6 \mathrm{Tg} \mathrm{C} \mathrm{yr}-1$ or $43.6 \mathrm{~kg} \mathrm{C} \mathrm{ha}^{-1} \mathrm{yr}^{-1}$ because of the increase in crop straw return. The contribution of straw return to carbon mitigation potential showed large divergences among maize, rice and wheat croplands in China. The crop straw return in maize contributed the largest carbon mitigation potential of $2.0 \mathrm{Tg} \mathrm{C} \mathrm{yr}^{-1}$, accounting for $53.9 \%$ of the total potential mitigation by this practice. The potentials from straw return in rice and maize croplands were 0.8 and $0.9 \mathrm{Tg} \mathrm{C} \mathrm{yr}^{-1}$, respectively. Henan and Shandong also had large mitigation potentials of 0.5 and $0.4 \mathrm{Tg} \mathrm{C} \mathrm{yr}^{-1}$ because of the large production of crop straw. Crop straw production in minimal in Tibet, and therefore, an increase in crop straws was only a small contribution, with carbon

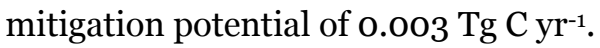

\subsection{Carbon mitigation potential by conservation tillage}

The total carbon mitigation potential with conservation tillage was $8.6 \mathrm{Tg} \mathrm{C} \mathrm{yr}^{-1}$ or $104.0 \mathrm{~kg} \mathrm{C}$ $\mathrm{ha}^{-1} \mathrm{yr}^{-1}, 99.8 \%$ of which was direct potential 
mitigation. Under conservation tillage, the contributions to carbon mitigation from rice, wheat and maize croplands were 3.0, 2.4, and $3.2 \mathrm{Tg} \mathrm{C} \mathrm{yr}^{-1}$, respectively. The largest mitigation potential of 0.8

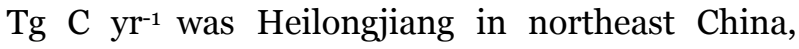
followed by Henan in north China with $0.7 \mathrm{Tg} \mathrm{C} \mathrm{yr}^{-1}$. Similar to the mitigation potential of the other practices, Tibet also had the smallest potential of $0.004 \mathrm{Tg} \mathrm{C} \mathrm{yr}^{-1}$ under conservation tillage, because of the limited area in cropland.

\subsection{The total carbon mitigation potential of the three practices combined}

Combined, the total carbon mitigation potential of the three practices was $38.8 \mathrm{Tg} \mathrm{C} \mathrm{yr}^{-1}$ in China, or $468.2 \mathrm{~kg} \mathrm{C} \mathrm{ha-1}^{-1} \mathrm{yr}^{-1}$ (Table 1). For China, the carbon mitigation potential represented an equivalent of $49.4 \%$ of the total $\mathrm{CO}_{2}$ emissions from cropland in 2008 and $1.6 \%$ of $\mathrm{CO}_{2}$ emissions from fossil fuels in 2011 (Le Quéréet al. 2013; Li et al. 2011). Thus, compared with the rapid increase in carbon emissions in China, the total carbon mitigation by these practices was very limited; however, the contributions remain essential to achieve Chinese carbon mitigation targets. Additionally, the direct carbon mitigation summed to $33.8 \mathrm{Tg} \mathrm{C} \mathrm{yr}^{-1}$, which was $87.0 \%$ of total potential of these three practices combined.

Furthermore, fertilizer substitution contributed the largest direct mitigation potential of $63.8 \%$, followed by that of conservation tillage with $25.4 \%$. The remaining mitigation was achieved by crop straw return. For the indirect carbon mitigation, fertilizer substitution with livestock manure was responsible for most of its

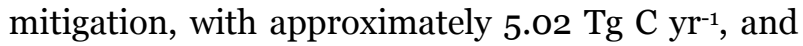
the remaining mitigation potential of $0.02 \mathrm{Tg} \mathrm{C} \mathrm{yr}^{-1}$ occurred under conservation tillage. Overall, fertilizer substitution was the largest contribution to carbon mitigation potentials, followed by conservation tillage and crop straw return. When the mitigation potentials of the three improved practices were combined, maize cropland had the largest carbon mitigation potential of $14.5 \mathrm{Tg} \mathrm{C} \mathrm{yr}^{-1}$, accounting for $37.3 \%$ of the total potential. Rice and wheat cropland also contributed large

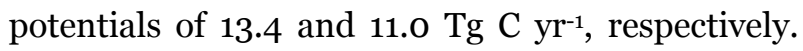
Geographically, south China had the largest carbon mitigation of $17.7 \mathrm{Tg} \mathrm{C} \mathrm{yr}^{-1}$, followed by northern
China with 11.8 $\mathrm{Tg} \mathrm{C} \mathrm{yr}^{-1}$, northeast China with 6.0 $\mathrm{Tg} \mathrm{C} \mathrm{yr}^{-1}$, and western China with $3.3 \mathrm{Tg} \mathrm{C} \mathrm{yr}^{-1}$. The two provinces with the largest mitigation potentials were Henan and Shandong because of the decrease in consumption of fertilizers and fossil fuels. However, the carbon mitigation potentials were

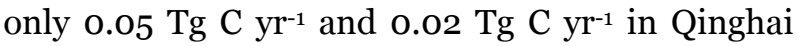
and Tibet, respectively, because of the limited cropland and limited consumption of fertilizers and fossil fuels.

\section{Discussion}

With the implementation of these improved practices, the total carbon mitigation potential was $38.8 \mathrm{Tg} \mathrm{C} \mathrm{yr}^{-1}$ for the three primary Chinese croplands, which was equivalent to $49.4 \%$ of $\mathrm{CO}_{2}$ emission from agriculture and $1.6 \%$ of $\mathrm{CO}_{2}$ emissions from fossil fuels. Although this mitigation potential is much smaller than the large increase in Chinese carbon emissions, this mitigation represents a substantial absolute potential to avoid further emissions. More importantly, these practices provide additional benefits for the long-term sustainability of crop cultivation in China, such as rebuilding soil carbon in depleted agricultural soils, reducing air pollution from open-field burning of crop straw, and improving soil organic carbon intensity.

\subsection{Regional differences for carbon mitigation potential}

Geographically, south China contributed the largest potential of $17.7 \mathrm{Tg} \mathrm{C} \mathrm{yr}^{-1}$, followed by northern China with $11.8 \mathrm{Tg} \mathrm{C} \mathrm{yr}^{-1}$, northeast China with 6.0 $\mathrm{Tg} \mathrm{C} \mathrm{yr}^{-1}$, and western China with $3.3 \mathrm{Tg} \mathrm{C}$ $\mathrm{yr}^{-1}$ (Table 2 and Figure 2). However, northwest China had the largest carbon mitigation potential per unit area, followed by northeast China, and both of their potentials were higher than the national average. The mitigation potentials were relatively small in north and south China.

Northwest China had the largest unit area potential of $538.9 \mathrm{~kg} \mathrm{C} \mathrm{ha-1} \mathrm{yr}^{-1}$, with the contribution of fertilizer substitution being the largest mitigation potential. In the northwest China, all provinces had higher mitigation potentials per unit area than the national average, with the largest 
Table 2 The potentials of carbon mitigation per area in different regions by improved cropland practices in China (Unit: $\mathrm{kg} \mathrm{C} \mathrm{ha}^{-1} \mathrm{yr}^{-1}$ )

\begin{tabular}{l|l|l|l|l|l|l|l|l|l|l|} 
Region & \multicolumn{2}{|c|}{ Fertilizer substitution } & \multicolumn{2}{c|}{ Crop straw return } & \multicolumn{2}{c|}{ Conservation tillage } & \multicolumn{2}{c|}{ All three practices together } \\
& Amount & Percent & Amount & Percent & Amount & Percent & $\begin{array}{l}\text { Total } \\
\text { Potential }\end{array}$ & $\begin{array}{l}\text { Direct } \\
\text { Potential }\end{array}$ & $\begin{array}{l}\text { Indirect } \\
\text { Potential }\end{array}$ \\
\hline Region I & 299.21 & $61.7 \%$ & 57.94 & $11.9 \%$ & 127.69 & $26.3 \%$ & 484.84 & 445.44 & 39.40 \\
Region II & 319.63 & $70.3 \%$ & 56.52 & $12.4 \%$ & 78.69 & $17.3 \%$ & 454.85 & 395.02 & 59.83 \\
Region III & 324.93 & $60.3 \%$ & 18.83 & $3.5 \%$ & 195.19 & $36.2 \%$ & 538.95 & 473.83 & 65.12 \\
Region IV & 327.35 & $71.0 \%$ & 34.19 & $7.4 \%$ & 99.19 & $21.5 \%$ & 460.73 & 393.19 & 67.54 \\
China & 320.53 & $68.5 \%$ & 43.64 & $9.3 \%$ & 104.01 & $22.2 \%$ & 468.18 & 407.46 & 60.72
\end{tabular}

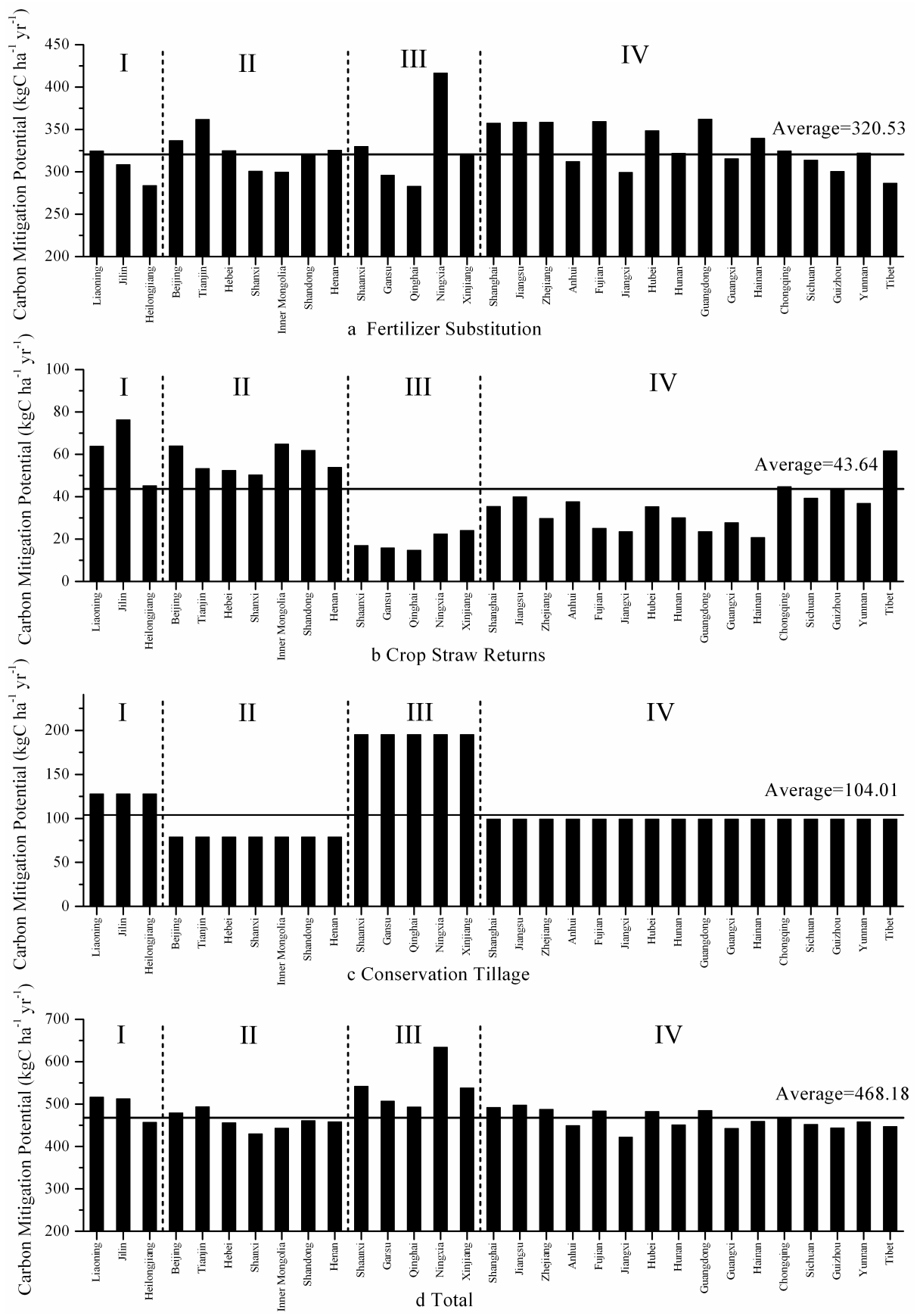

Figure 2 Cropland carbon mitigation potential per area with improved cropland practices in China. potential in Ningxia. The local climate is semi-arid in these areas and soil erosion caused by conventional tillage and deforestation can be extensive; thus, with the application of conservation tillage to this area, the carbon mitigation potential of

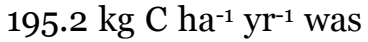
very high. Because of the long-term and historical soil erosion in this region, intensive fertilizer applications are required, and therefore, by substituting chemical fertilizers with manure, the carbon mitigation potential was large. However, because of limited crop straw production in northwest China, less crop straw would be returned back. Thus, the mitigation potential from the return of crop straw was much lower than that of the national level there.

Northeast China is famous for the local fertile soils with high 
Table 3 The carbon mitigation potentials in rice, wheat and maize croplands in four regions (Unit: million ha for area and $\mathrm{Tg} \mathrm{C} \mathrm{yr}^{-1}$ for the carbon mitigation potential)

\begin{tabular}{|c|c|c|c|c|c|c|c|c|c|}
\hline \multirow{2}{*}{ Region } & \multicolumn{3}{|c|}{ Rice } & \multicolumn{3}{|c|}{ Wheat } & \multicolumn{3}{|c|}{ Maize } \\
\hline & Area & Potential & Percent & Area & Potential & Percent & Area & Potential & Percent \\
\hline Region I & 3.71 & 1.69 & $28.0 \%$ & 0.28 & 0.12 & $2.1 \%$ & 8.45 & 4.22 & $70.0 \%$ \\
\hline Region II & 0.93 & 0.41 & $3.5 \%$ & 12.52 & 5.57 & $47.1 \%$ & 12.56 & 5.84 & $49.4 \%$ \\
\hline Region III & 0.28 & 0.16 & $5.0 \%$ & 3.23 & 1.71 & $52.6 \%$ & 2.51 & 1.38 & $42.4 \%$ \\
\hline Region IV & 24.32 & 11.14 & $62.8 \%$ & 7.75 & 3.55 & $20.0 \%$ & 6.39 & 3.03 & $17.1 \%$ \\
\hline Total & 29.24 & 13.40 & $34.5 \%$ & 23.79 & 10.95 & $28.2 \%$ & 29.92 & 14.48 & $37.3 \%$ \\
\hline
\end{tabular}

carbon storage; thus, compared with conventional tillage practices, conservation tillage was beneficial in the mitigation of carbon emissions from these soils. However, also because of the local fertile soils, fertilizers consumption in this region is low, and therefore, fertilizer substitution with manure proved only a relatively small carbon mitigation potential. Maize is the dominant crop in northeast China and there are a large area of maize cropland. Consequently, with high straw-grain ratio crop straw return contributed to a relatively high carbon mitigation potential, compared with other regions.

North and south China had relatively low carbon mitigation potential per unit area. The low soil fertility results in much larger consumption of fertilizers than that in other regions, and therefore, fertilizer substitution had relatively large carbon mitigation potential in these two regions. Moreover, conventional tillage had a much smaller effect on the local soil carbon stock, compared with that in northeast and northwest China. Rice is the dominant crop in south China, with a low strawgrain. Therefore, crop straw production in south China is relatively low, and crop straw return contributed only a small mitigation potential in south China.

Overall, with fertilizer substitution, northwest and south China had large carbon mitigation potential per unit area because of the local extreme consumption of fertilizers; for crop straw return, northeast and north China had relatively high carbon mitigation potentials per unit area; and with conservation tillage, northwest and northeast China had high carbon mitigation potentials per unit area.

\subsection{Comparison analysis among three croplands in China}

For the combined effects of these three mitigation practices, maize cropland had the largest carbon mitigation potential of $14.5 \mathrm{Tg} \mathrm{C} \mathrm{yr}^{-1}$, followed by rice and wheat croplands (Table 3 , Figure 3). In northeast China, rice and maize croplands contributed the most potential to the total carbon mitigation potentials, with the contribution of wheat cropland only being $2.1 \%$. In northeast China, the scenario was similar with all provinces. In north China, wheat and maize contributed $47.1 \%$ and $49.4 \%$ to total mitigation potential, respectively. However significant differences were detected among provinces, because the dominant crops are different; wheat cropland are dominant in Shandong and Henan, while maize is the primary crop in the other 5 provinces. Maize contributed the largest proportion of mitigation potentials in all provinces in northwest China. In south China, the largest contribution was from rice in most provinces (with the only exceptions of Anhui and Tibet), which accounted for $62.8 \%$ of the total potential, but maize and wheat also contributed $3.55 \mathrm{Tg} \mathrm{C} \mathrm{yr}^{-1}$ and

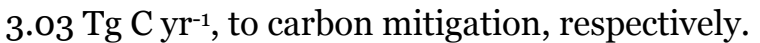

Rice cropland: The largest contribution of rice to the mitigation potential was $1.77 \mathrm{Tg} \mathrm{C} \mathrm{yr}^{-1}$ in

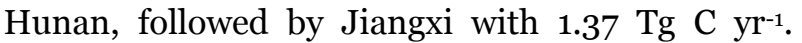
Nine other provinces had potentials from rice

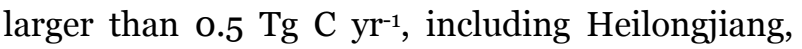
Jiangsu, Anhui, Jiangxi, Hubei, Guangdong, Hunan, Guangxi, and Sichuan. Because of the local weather, only a few cropland areas of rice are found in northwest China and north China; thus no province in these two regions contributed more than $0.5 \mathrm{Tg} \mathrm{C} \mathrm{yr}^{-1}$ of carbon mitigation potential from rice cropland.

Wheat cropland: With the climate suitable, wheat is the primary important food crop in north and northwest China, and large areas of wheat cropland are found in these two areas; thus, wheat cropland had relatively large carbon mitigation potentials in the provinces of these regions. In northeast and south China, because of the limited wheat cropland, the contribution of most provinces to carbon mitigation potentials was limited. 


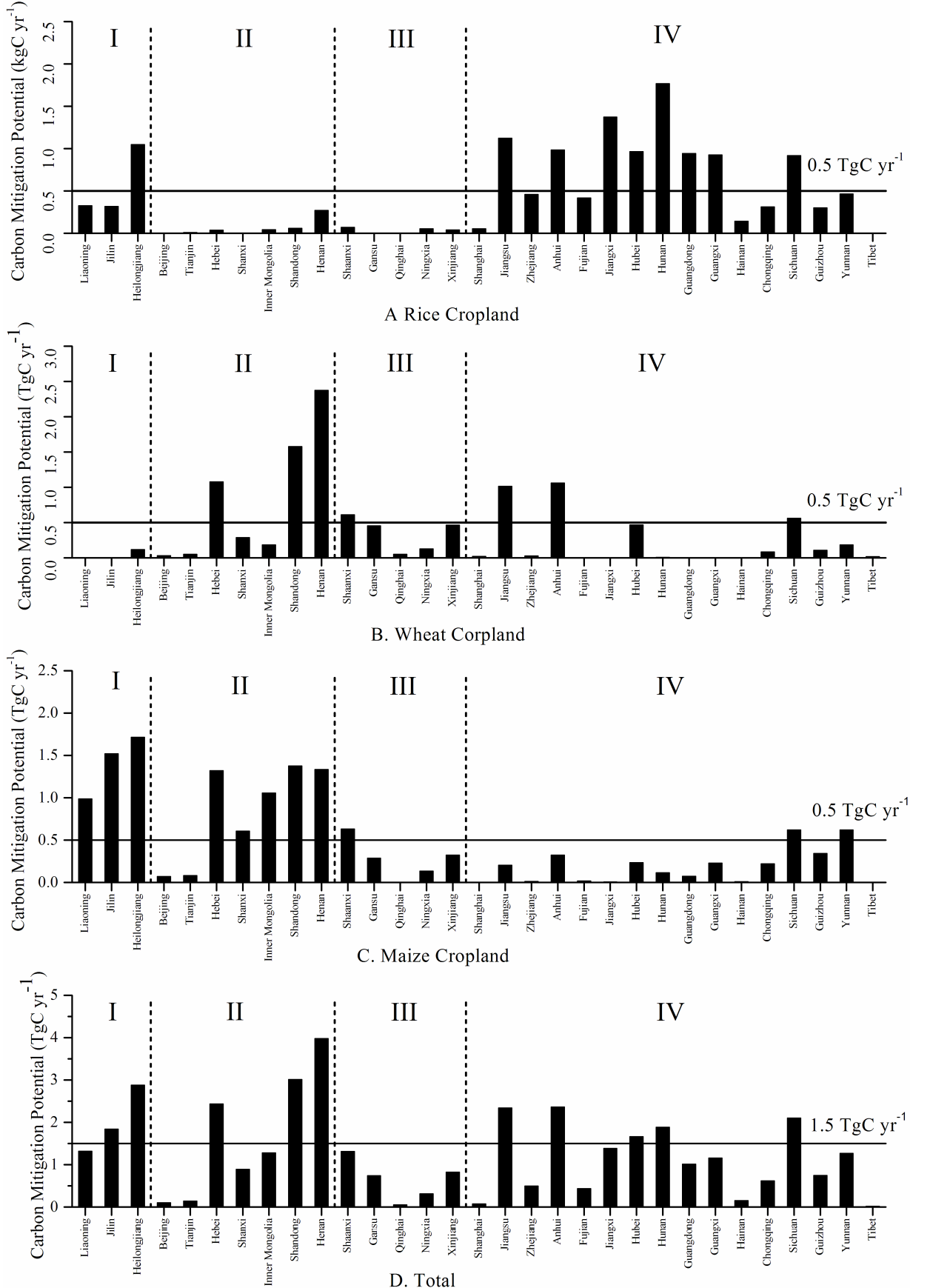

Figure 3 Carbon mitigation potentials in rice, wheat and maize croplands in China.

Shandong, Henan and Hebei. In northwest and south China, carbon mitigation potentials were relatively small from maize cropland and only three provinces (Shaanxi, Sichuan, and Yunnan) had mitigation potential of more than $0.5 \mathrm{Tg} \mathrm{C} \mathrm{yr}^{-1}$.

\subsection{Cropland carbon mitigation and regional cooperation}

At the Conference of the Parties 15 of the United Nations Framework Convention on Climate Change in Copenhagen, the Chinese government committed to the implementation of the 2020 carbon reduction target of $40 \%-$ $45 \%$ below the 2005 level of carbon emission intensity (Fan and Xia 2012). As calculated above, the three improved practices provided a total carbon mitigation potential of $38.8 \mathrm{Tg} \mathrm{C}_{\mathrm{Cr}}^{-1}$ in China, equivalent to $49.4 \%$ of $\mathrm{CO}_{2}$ emissions from agriculture and $1.6 \%$ of $\mathrm{CO}_{2}$ emissions from fossil

However, wheat cropland contributed more than

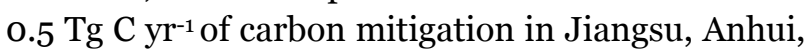
and Sichuan.

Maize cropland: Maize has an important role in local diet in north and northeast China, which is supported by large areas of maize cropland in these two regions. With the exceptions of Beijing and Tianjin, the potential from maize cropland was more than $0.5 \mathrm{Tg} \mathrm{C} \mathrm{yr}^{-1}$ in all other provinces, particularly in Heilongjiang, Jilin, fuels. However, significant differences were found for carbon mitigation potentials among provinces in China. For example, based on a comparison of carbon emissions in one previous study (Li et al. 2011), the combined mitigation potential of the three practices in Heilongjiang was 95\% of the cropland carbon emissions; whereas in Zhejiang, the combined contribution was only $19 \%$ of total cropland carbon emissions.

Soil carbon sequestration and carbon emission 
mitigation were included in the Kyoto Protocol and can be used for carbon trading for a "Clean Development Mechanism" (CDM) or in an "Emission Trading Scheme" (ETS) (Jawson et al. 2005). Thus, we compared the cropland carbon mitigation targets with soil carbon sequestration potential (i.e., the direct cropland carbon mitigation). When the mitigation potential was larger than the target, we assumed it was a "target surplus"; whereas, we assumed it was a "target deficit" when the mitigation potential was less than the reduction target.

Using the results from $\mathrm{Li}$ et al. (2011), we calculated the carbon reduction target (40\% of carbon emissions in 2005) for Chinese cropland by 2020. The relationship between cropland carbon mitigation target and soil carbon sequestration potential is illustrated in Figure 4. We concluded that 18 provinces had the "target surplus", with the implementation of the improved cropland practices.

However, 13 provinces in China (with the exceptions of Hong Kong, Macao and Taiwan) remained with "target deficits", including Beijing, Tianjin, and Hebei in northeast China, Qinghai and Xinjiang in northwest China, in addition to
Shanghai, Zhejiang, Fujian, Hunan, Guangxi, Hainan and Tibet in south China. In these provinces, the cropland carbon mitigation potentials of these improved practices did not meet the mitigation targets. The largest "target deficit" was $0.54 \mathrm{Tg} \mathrm{C} \mathrm{yr}^{-1}$ in Zhejiang, indicating that further improvements in cropland practices are required to mitigate carbon emissions or carbon credits must be bought to meet their targets.

The use of these improved practices in Heilongjiang contributed to the largest "target surplus" of $1.62 \mathrm{Tg} \mathrm{C} \mathrm{yr}^{-1}$ in China, followed by Henan (0.70 Tg C yr-1) and Sichuan (0.63 $\left.\mathrm{TgC} \mathrm{yr}^{-1}\right)$. This "target surplus" can be credited for domestic or international carbon trading. Taking all provinces as a whole, the total "target surplus" was 7.10 $\mathrm{Tg} \mathrm{C} \mathrm{yr}^{-1}$, whereas the total "target deficits" was only $2.26 \mathrm{Tg} \mathrm{C} \mathrm{yr}^{-1}$. Thus, "target deficits" in the 13 provinces could be fully compensated for domestic carbon trading. Additionally, a further $4.84 \mathrm{Tg} \mathrm{C} \mathrm{yr}^{-1}$ of "carbon mitigation potential" from Chinese cropland could be traded with the implementation of the three improved practices combined.

Apart from "CDM" or "ETS", regional

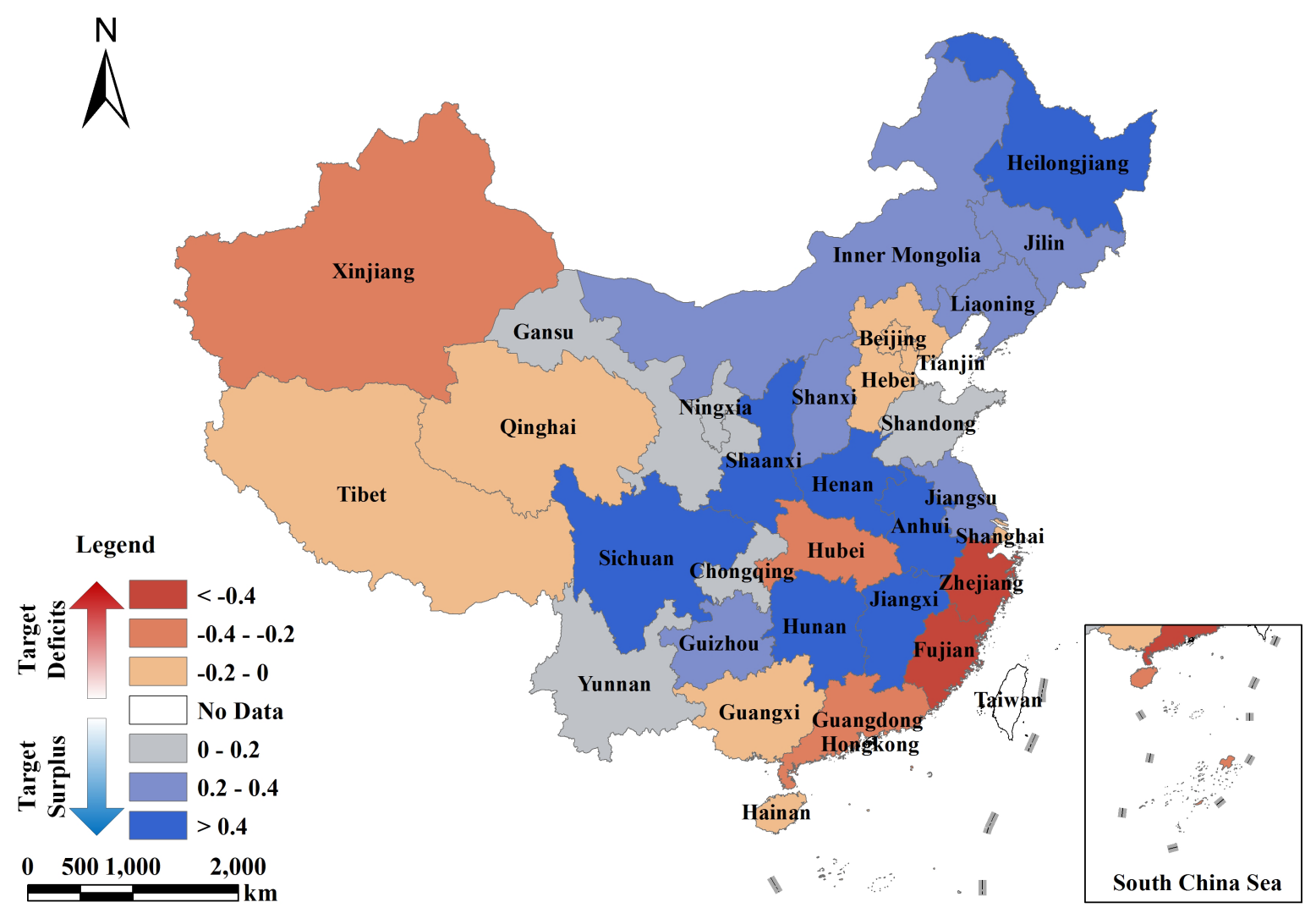

Figure 4 The map of cropland "target surplus" and "target deficits" in China. 
cooperation for carbon mitigation can also be achieved with regional associations (such as the "Association of Southeast Asian Nations") and research programs (such as GRACEnet (greenhouse gas reduction through agricultural carbon enhancement network) in the U.S) (Jawson et al. 2005; Lee et al. 2013). ASEAN aims to cooperate in the adaptation to and the alleviation of global warming with the principles of equity, flexibility, and effectiveness (Lee et al. 2013). For GRACEnet, the aims are to identify and develop agricultural strategies that will increase soil $\mathrm{C}$ sequestration and reduce greenhouse gas emissions, in addition to providing a scientific basis for possible carbon credit and trading programs (Jawson et al. 2005). Thus, regional associations and research programs can also be developed to enhance soil carbon sequestration, to reduce carbon mitigation requirements, and to provide credits for carbon trading.

\subsection{Discussion of other greenhouse gases, mitigation practices and interactive effects}

After $\mathrm{CO}_{2}, \mathrm{CH}_{4}$ and $\mathrm{N}_{2} \mathrm{O}$ are the largest contributors to human-induced climate change (Denman et al. 2007). Manure input and straw return increase soil carbon sequestration and avoid some of the carbon emissions; however, the emissions of cropland $\mathrm{CH}_{4}$ and $\mathrm{N}_{2} \mathrm{O}$ also increase with these practices. With the improved cropland practices, however, the currently disposed of useless livestock excreta and crop straw is used, which also emit $\mathrm{CH}_{4}$ and $\mathrm{N}_{2} \mathrm{O}$ during decomposition and open-field burning. Thus, based on the net balance, the improved practices in this study did not reduce the further increase in $\mathrm{CH}_{4}$ and $\mathrm{N}_{2} \mathrm{O}$ emissions. In this study, we adopted a conservative approach because of the lack of sufficient regional data and considered that there was no change in total emissions between the two possible fates of manure and crop residues.

Moreover, we did not consider other mitigation practices that reduce emissions of $\mathrm{CH}_{4}$ and $\mathrm{N}_{2} \mathrm{O}$ (Smith et al. 2007; Smith et al. 2013). For example, improved water management for rice cultivation leads to significant reductions in $\mathrm{CH}_{4}$ emissions by shifting from continuous flooding to mid-season drainage (Zhou et al. 2013; Li et al.
2005). For $\mathrm{N}_{2} \mathrm{O}$ emissions, many options are available to reduce excess nitrogen inputs and to improve nitrogen use efficiency in cropland systems (Tian et al. 2013).

Additionally, apart from the improved practices discussed above, many other improved practices increase soil carbon sequestration. In recent studies, the persistent carbon sink is $\mathrm{C}$ occluded within plant phytoliths, and rice, wheat and maize are the predominant dominant phytolith producing crop species (Parr and Sullivan 2011; Song et al. 2014; 2015; Guo et al. 2015). The size of this soil carbon sink has doubled since 1978, which should attract more attention to this persistent pool, and many improved agricultural management practices can further increase the sink of cropland phytolith C (Song et al. 2014).

Furthermore, in the current study, we focused on the three practices separately to estimate their carbon mitigation potentials and then summed the potentials of the three practices. However, when the three practices are applied together, the interactive effects among these three practices may influence the total carbon mitigation potential. Additionally, different cropland with different land-use type could have different carbon emissions, which is also should be considered in future research. Therefore, in the future, the influences of combined practices on carbon mitigation potential should be the focus of research, in addition to examining the mitigation potentials of other practices.

\section{Conclusion}

We estimated the carbon mitigation potential for rice, wheat and maize croplands in China with the implementation of three improve cropland practices, i.e., fertilizer substitution, crop straw return and conservation tillage. Combined, the three practices had a total carbon mitigation potential of $38.8 \mathrm{Tg} \mathrm{C} \mathrm{yr}^{-1}\left(468.2 \mathrm{~kg} \mathrm{C} \mathrm{ha}^{-1} \mathrm{yr}^{-1}\right)$ in China. However, these three practices affected mitigation potentials differently, with the largest mitigation potential of $26.6 \mathrm{Tg} \mathrm{C} \mathrm{yr}^{-1}$ with fertilizer substitution. For the different croplands, the carbon mitigation potentials were not significantly different.

However, because of local diets and weather, 
carbon mitigation potentials and the effects of the improved practices diverged significantly among provinces in China. When cropland carbon mitigation potentials were compared with their carbon reduction targets, 18 provinces met their cropland carbon mitigation targets with these three practices, whereas the other 13 provinces remained with a "target deficit". However, with the three practices combined, the national cropland carbon reduction target could be achieved through regional cooperation, with an additional carbon reduction of $4.84 \quad \mathrm{Tg} \quad \mathrm{C} \quad \mathrm{yr}^{-1}$ available for international or national carbon trading. Thus, the three improved agriculture practices could be very

\section{References}

Aertsens J, De Nocker L, Gobin A (2013) Valuing the carbon sequestration potential for European agriculture. Land Use Policy 31: 584-594. DOI: 10.1016/j.landusepol.2012.09.003

Augustin L, Barbante C, Barnes PRF, et al. (2004) Eight glacial cycles from an Antarctic ice core. Nature 429: 623-628. DOI: 10.1038/nature02599

Baker JM, Ochsner TE, Venterea RT, et al. (2007) Tillage and soil carbon sequestration - What do we really know? Agriculture Ecosystems \& Environment 118: 1-5. DOI: 10.1016/j.agee.2006.05.014

Cheng K, Ogle SM, Parton WJ, et al. (2014) Simulating greenhouse gas mitigation potentials for Chinese Croplands using the DAYCENT ecosystem model. Global Change Biology 20: 948-962. DOI: $10.1111 /$ gcb.12368

Cheng K, Zheng J, Nayak D, et al. (2013) Re-evaluating the biophysical and technologically attainable potential of topsoil carbon sequestration in China's cropland. Soil Use Manage 29: 501-509. DOI: 10.1111/sum.12077

Chuai X, Huang X, Wang W, et al. (2015) Land use, total carbon emission's change and low carbon land management in Coastal Jiangsu, China. Journal of Cleaner Production 103: 77-86. DOI: 10.1016/j.jclepro.2014.03.046

Denman KL, Brasseur G, Chidthaisong A, et al. (2007) Couplings between changes in the climate system and biogeochemistry. IPCC, 2007: Climate Change 2007: the physical science basis. Contribution of Working Group I to the Fourth Assessment Report of the Intergovernmental Panel on Climate Change. Solomon S, Qin D, Manning M, et al. (Eds.). Cambridge, U.K.: Cambridge University Press.

Dixon RK, Brown S, Houghton RA, et al. (1994) Carbon pools and flux of global forest ecosystems. Science 263: 185-189. DOI: $10.1126 /$ science.8023136

Fabrizzi KP, Rice CW, Amado TJC, et al. (2009) Protection of soil organic $\mathrm{C}$ and $\mathrm{N}$ in temperate and tropical soils: effect of native and agroecosystems. Biogeochemistry 92(1-2): 129-143. DOI: $10.1007 /$ s10533-008-9261-0

Fan M, Shen J, Yuan L, et al. (2012) Food security: improving crop productivity and resource use efficiency to ensure food security and environmental quality in China. Journal of experimental botany 63: 13-24. DOI: $10.1093 / j x b / e r r 248$

Fan Y, Xia Y (2012) Exploring energy consumption and demand in China. Energy 40: 23-30. DOI: 10.1016/j.energy.2011.09. 049

Frank S, Schmid F, Havlík P, et al. (2015) The dynamic soil useful in mitigating carbon emissions in China. Additionally, to better achieve carbon mitigation targets, regional cooperation is extremely import in implementing carbon trading, establishing regional associations, and conducting research programs, in addition to improving other management practices.

\section{Acknowledgements}

This study was supported by the National Science and Technology Major Project (2015ZX07203-005), the National Program for Support of Top-notch Young Professionals.

organic carbon mitigation potential of European cropland Global Environmental Change 35: 269-278. DOI: 10.1016/ j.gloenvcha.2015.08.004

Freibauer A, Rounsevell M, Smith P, et al. (2004) Carbon sequestration in the agricultural soils of Europe. Geoderma 122: 1-23. DOI: 10.1016/j.geoderma.2004.01.021

Guo F, Song Z, Sullivan L, et al. (2015) Enhancing phytolith carbon sequestration in rice ecosystems through basalt powder amendment. Science Bulletin 6o(6): 591-597. DOI: 10.1007/s11434-015-0729-8

Han B, Kong F, Zhang H, et al. (2010) Effect of tillage conversion on carbon sequestration capability of farmland soil doubled cropped with wheat and corn. The Journal of Applied Ecology 21(1): 91-98. (In Chinese)

Han B, Wang X, Ouyang Z (2005) Saturation levels and carbon sequestration potentials of soil carbon pools in farmland ecosystems of China. Rural Eco-Environment 21(4): 6-11. (In Chinese)

Huang T, Gao B, Christie P, et al. (2013) Net global warming potential and greenhouse gas intensity in a double-cropping cereal rotation as affected by nitrogen and straw management. Biogeosciences 10: 897-7911. DOI: $10.5194 / \mathrm{bg}-10-7897-2013$

Huang S, Sun Y, Zhang W (2012) Changes in soil organic carbon stocks as affected by cropping systems and cropping duration in China's paddy fields: a meta-analysis. Climate Change 112: 847-858. DOI: 10.1007/s10584-011-0255-X

Huang Y, Sun W (2006) Changes in topsoil organic carbon of croplands in mainland China over the last two decades. Chinese Science Bulletin 51(15): 1785-1803. DOI: 10.1007/ s11434-006-2056-6

IPCC (2007) Climate Change 2007: Mitigation. Contribution of Working Group IIIto the Fourth Assessment Report of the Intergovernmental Panel on Climate Change. Cambridge University Press, Cambridge, UK/New York, USA.

Jawson MD, Shafer SR, Franzluebbers AJ, et al. (2005) GRACEnet: Greenhouse gas reduction through agricultural carbon enhancement network. Soil \& Tillage Research 83: 167-172. DOI: DOI:10.1016/j.still.2005.02.015

Lal R (2004) Carbon emission from farm operations. Environment International 30: 981-990. DOI: 10.1016/ j.envint.2004.03.005

Lal R (2007) Carbon management in agricultural soils. Mitigation and adaptation strategies for global change 12: 303-322. DOI: 10.1007/s11027-006-9036-7 
Lal R, Follett RF, Kimble JM (2003) Achieving Soil Carbon Sequestration in the United States: A Challenge to the Policy Makers. Soil Science 168: 827-845. DOI: 10.1097/01.ss. 0000106407.84926.6b

Le Quéré C, Andres RJ, Boden T, et al. (2013) The global carbon budget 1959-2011. Earth System science data 5: 165-185. DOI: 10.5194/essd-5-165-2013

Lee ZH, Sethupathi S, Lee KT, et al. (2013) An overview on global warming in Southeast Asia: $\mathrm{CO}_{2}$ emission status, efforts done, and barriers. Renewable and Sustainable Energy Reviews 28: 71-81. DOI: 10.1016/j.rser.2013.07.055

Li B, Zhang J, Li H (2011) Research on Spatial-temporal Characteristics and Affecting Factors Decomposition of Agricultural Carbon Emission in China. China Population, Resources and Environment 21(8): 80-86. (In Chinese)

Li C, Xiao X, Frolking S, et al. (2003) Greenhouse gas emissions from croplands of China. Quaternary Sciences 23(5): 493-503. (In Chinese)

Li C, Frolking S, Xiao X, et al. (2005) Modeling impacts of farming management alternatives on $\mathrm{CO}_{2}, \mathrm{CH}_{4}$ and $\mathrm{N}_{2} \mathrm{O}$ emissions: A case study for water management of rice agriculture of China. Global Biogeochemical Cycles 19(3): GB3010. DOI: 10.1029/2004GBo02341

Li C, Kou Z, Zhang Z, et al. (2011) Effects of rape residue mulch on greenhouse gas emissions and carbon sequestration from conservation tillage rice fields. Journal of Agro-Environment Science 30(11): 2362-2367. (In Chinese)

Lu F, Wang X, Han B, et al. (2010) Straw return to rice paddy: soil carbon sequestration and increased methane emission. Chinese Journal of Applied Ecology 21(1): 99-108. (In Chinese)

Lu F, Wang X, Han B, et al. (2009) Soil carbon sequestrations by nitrogen fertilizer application, straw return and no-tillage in China's cropland. Global Change Biology 15: 281-305. DOI: 10.1111/j.1365-2486.2008.01743.x

Müller C, Elliott J, Chryssanthacopoulos J, et al. (2015) Implications of climate mitigation for future agricultural production. Environmental Research Letters 10: 125004. DOI: 10.1088/1748-9326/10/12/125004

Nayak D, Saetnan E, Cheng K, et al. (2015) Management opportunities to mitigate greenhouse gas emissions from Chinese agriculture. Agricultural Ecosystems \& Environment 209: 108-124. DOI: 10.1016/j.agee.2015.04.035

Ouyang X, Zhou X, Wang Y (2011) Progress in Functions of organic agriculture in soil sequestration and biodiversity. Chinese Agricultural Science Bulletin 27(11): 224-230. (In Chinese)

Pacala S, Socolow R (2004) Stabilization wedges: solving the climate problem for the next 50 years with current technologies. Science 305: 968-972. DOI: 10.1126/science. 1100103

Pan G, Li L, Wu L, et al. (2003) Storage and sequestration potential of topsoil organic carbon in China's paddy soils. Global Change Biology 10: 79-92. DOI: 10.1111/j.1365-2486. 2003.00717.x

Pan G, Smith P, Pan W (2009) The role of soil organic matter in maintaining the productivity and yield stability of cereals in China. Agriculture Ecosystems \& Environment 129: 344-348. DOI: $10.1016 /$ j.agee.2008.10.008

Pan G, Zhou P, Li Z, et al. (2009) Combined inorganic/organic fertilization enhances $\mathrm{N}$ efficiency and increases rice productivity through organic carbon accumulation in a rice paddy from the Tai Lake region, China. Agriculture Ecosystems \& Environment 131: 274-280. DOI: 10.1016/ j.agee.2009.01.020

Parr J, Sulliva L (2011) Phytolith occluded carbon and silica variability in wheat cultivars. Plant and Soil 342: 165-171. DOI: 10.1007/s11104-010-0680-Z

Paustian K, Six J, Elliott E, et al. (2000) Management options for reducing $\mathrm{CO}_{2}$ emissions from agricultural soils. Biogeochemistry 48:147-163. DOI:10.1023/A:1006271331703

Peters GP, Davis SJ, Andrew R (2012) A synthesis of carbon in international trade. Biogeosciences 9: 3247-3276. DOI: 10.5194/bg-9-3247-2012

Ponsioen TC, Blonk T J (2012) Calculating land use change in carbon footprints of agricultural products as an impact of current land use. Journal of Cleaner Production 28: 120-126. DOI: $10.1016 /$ j.jclepro.2011.10.014

Qiu H, Mo H, Bai J, et al. (2012) Analysis of treatment and its factors of livestock manure in rural China: based on the surveys in five provinces. China Rural Economy 3: 78-87. (In Chinese)

Qiu J, Li C, Wang L, et al. (2009) Modeling impacts of carbon sequestration on net greenhouse gas emissions from agricultural soils in China. Global Biogeochemical Cycles 23(1): GB1007. DOI: 10.1029/2008GBoo3180

Sanchez B, Iglesias A, McVittie A, et al. (2016) Management of agricultural soils for greenhouse gas mitigation: Learning from a case study in NE Spain. Journal of Environmental Management 170: 37-49. DOI: 10.1016/j.jenvman.2016.01. 003

Schimel DS, House JI, Hibbard KA, et al. (2001) Recent patterns and mechanisms of carbon exchange by terrestrial ecosystems. Nature 414: 169-172. DOI: 10.1038/35102500.

Shen M, Yang L, Yao Y, et al. (2007) Long-term effects of fertilizer managements on crop yields and organic carbon storage of a typical rice-wheat agroecosystem of China. Biology and Fertility of Soils 44: 187-200. DOI: 10.1007/ so0374-007-0194-x

Smith P (2004) Carbon sequestration in croplands: the potential in Europe and the global context. European Journal of Agronomy 20: 229-236. DOI: 10.1016/j.eja.2003.08.002

Smith P, Martino D, Cai Z, et al. (2007) Policy and technological constraints to implementation of greenhouse gas mitigation options in agriculture. Agriculture Ecosystems \& Environment 118(1): 6-28. DOI: 10.1016/j.agee.2006.06.006 Smith P, Martino D, Cai Z, et al. (2008) Greenhouse gas mitigation in agriculture. Philosophical Transactions of the Royal Society B 363: 789-813. DOI: 10.1098/rstb.2007.2184.

Smith P, Powlson D, Smith J, et al. (2006) Meeting Europe's climate change commitments: quantitative estimates of the potential for carbon mitigation by agriculture. Global Change Biology 6: 525-539. DOI: 10.1046/j.1365-2486.2000.00331.x

Smith P, Haberl H, Popp A., et al. (2013) How much land - based greenhouse gas mitigation can be achieved without compromising food security and environmental goals? Global Change Biology 19(8): 2285-2302. DOI: 10.1111/gcb. 12160

Song Z, Müller K, Wang H (2014) Biogeochemical silicon cycle and carbon sequestration in agricultural ecosystems. EarthScience Reviews 139: 268-278. DOI: 10.1016/j.earscirev.2014. 09.009

Song Z, Wang H, Strong P, et al. (2014) Phytolith carbon sequestration in China's croplands. European Journal of Agronomy 53: 10-15. DOI: 10.1016/j.eja.2013.11.004

Sun J, Peng H, Chen J, et al. (2016) An estimate of $\mathrm{CO}_{2}$ emission via agricultural crop residue open field burning in China from 1996 to 2013. Journal of Cleaner Production 112: 2625-2631. DOI: 10.1016/j.jclepro.2015.09.112

Sun J, Zhao R, Huang X, et al. (2010) Research on carbon emission estimation and factor decomposition of China from 1995 to 2005. Journal of Natural Resources 25(8): 1284-1295. (In Chinese)

Sun T, Song X (2008) Problems on Chinese Agricultural Environmental and Countermeasures. Research of Agricultural Modernization 29(6): 646-649. (In Chinese)

Sun Y, Li G, Zhang F, et al. (2005) Status quo and developmental strategy of agricultural residues resources in China. Transactions of the Chinese Society of Agricultural Engineering 21(8): 169-173. (In Chinese)

Triberti L, Nastri A, Giordani G, et al. (2008) Can mineral and organic fertilization help sequestrate carbon dioxide in cropland? European Journal of Agronomy 29: 13-20. DOI: 10.1016/j.eja.2008.01.009

Wang H, Qin Y, Yu K (2008) Utilization, distribution and 
exploitation tactics of crop stalk resources in China. Territory and Natural Resources Study 2: 92-93.

Wang W, Guo L, Li G, et al. (2015) Greenhouse gas intensity of three main crops and implications for low-carbon agriculture in China. Climatic Chang 128: 57-70. DOI: 10.1007/s10584014-1289-7

Wang W, Koslowski F, Nayak D, et al. (2014) Greenhouse gas mitigation in Chinese agriculture: Distinguishing technical and economic potentials. Global Environmental Change 26: 53-62. DOI: 10.1016/j.gloenvcha.2014.03.008

West TO, Marland G (2002a) Net carbon flux from agricultural ecosystems: methodology for full carbon cycle analyses. Environmental Pollution 116, 439-444. DOI: 10.1016/So2697491(01)00221-4

West TO, Marland G (2002b) A synthesis of carbon sequestration, carbon emissions, and net carbon flux in agriculture: comparing tillage practices in the United States. Agriculture Ecosystems \& Environment 91: 217-232. DOI: 10.1016/So167-8809(01)00233-X

West T. Post W (2002c) Soil organic carbon sequestration rates by tillage and crop rotation: a global data analysis. Soil Science Society of America Journal 66(6): 1930-1946.

Wright AL, Hons FM (2005) Soil carbon and nitrogen storage in aggregates from different tillage and crop regimes. Soil Science Society of America Journal 69(1): 141-147.

Wu L, Li L, Zhang H, et al. (2007) Effects of conservation tillage on net carbon flux from farmland ecosystems. Chinese
Journal of Ecology 26(12): 2035-2039. (In Chinese)

Xu S, Huang G, Li Y (2011) The Research Progress about Effects of agricultural measures on soil carbon content. Chinese Agricultural Science Bulletin 27(7): 259-264. (In Chinese)

$\mathrm{Xu} \mathrm{X}$, Shi X, Zhao Y, et al. (2012) Simulation of carbon sequestration potential from paddy fields in Jiangsu Province under different tillage practices. Soils 44(2): 253-259. (In Chinese)

Yan M, Cheng K, Luo T, et al (2015) Carbon footprint of grain crop production in China - based on farm survey data. Journal of Cleaner Production 104: 130-138. DOI: 10.1016/ j.jclepro.2015.05.058

Yan H, Cao M, Liu J, et al. (2007) Potential and sustainability for carbon sequestration with improved soil management in agricultural soils of China. Agriculture Ecosystems \& Environment 121: 325-335. DOI: 10.1016/j.agee.2006.11.008

Zhang F, Wang J, Zhang W, et al. (2008) Nutrient use efficiencies of major cereal crops in China and measures for improvement. Acta Pedologica Sinica 45(5): 915-924. (In Chinese)

Zhou S, Song X, Yan X (2013) Progress in Research on Lowcarbon Rice Production Technology. Chinese Journal of Rice Science 27(2): 213-222. (In Chinese)

Zhu L, Yang M, Xu M, et al. (2012) Effects of different fertilization modes on paddy field topsoil carbon content and carbon sequestration duration in South China. Chinese Journal of Applied Ecology 23(1): 87-95. (In Chinese) 